\title{
Operation and cleaning of ceramic membranes for the filtration of fish press liquor
}

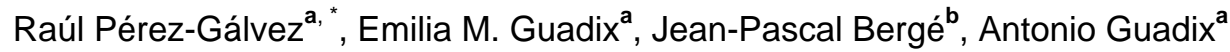 \\ a Departamento de Ingeniería Química, Universidad de Granada, 18071 Granada, Spain \\ ${ }^{\mathrm{b}}$ Laboratoire Sciences et Technologie de la Biomasse Marine, IFREMER, 44311 Nantes, France \\ *: Corresponding author : Raúl Pérez-Gálvez, Tel.: +34 958243308 ; fax: +34 958248992 ; \\ email address : rperezga@ugr.es
}

\begin{abstract}
:
This paper assesses the performance of three ceramic membranes of average pore size $50 \mathrm{~nm}, 200$ $\mathrm{nm}$ and $1.4 \mu \mathrm{m}$ in the treatment of the press liquor resulting from a compaction operation of sardine by-products. To this end, $2 \mathrm{~L}$ of pre-filtered press liquor with an average protein content of $44 \mathrm{~g} / \mathrm{L}$ were filtered during $3 \mathrm{~h}$ through the three membranes assayed. Unexpectedly, the membrane of larger pore size, presented the lowest values for the flux of permeate at steady state at $20 \mathrm{~L} /\left(\mathrm{m}^{2} \mathrm{~h}\right)$, while its average protein rejection (77\%) was similar to that observed in the membrane of $200 \mathrm{~nm}$. This fact was attributed to the difference in material of its active layer ( $\alpha$-alumina instead of zirconite). The cleaning efficiency of the membranes was assessed by the COD reduction in the permeate streams, related to that of the raw press liquor. The permeates obtained from the three membranes presented an average value of COD around $17,300 \mathrm{mg} \mathrm{O} / \mathrm{L}$, which corresponds to a COD removal efficiency above $85 \%$. Finally, a cleaning protocol comprising an alkali, acid and final disinfection stage was performed after the ultrafiltration. This sequence permitted to restore completely the initial permeability for the three membranes, although the acid step was found to be detrimental to the cleaning efficiency.
\end{abstract}

\section{Highlights}

Ceramic membranes able to remove up to $87 \%$ of COD of fish press juices. Flux of permeate was satisfactorily fitted to a cake-forming model. Material of active layer showed influence on both fouling and protein transmission. A 3-stage cleaning protocol restored the permeability of the fouled membranes. Nitric acid exhibited a detrimental effect on the membrane cleaning.

Keywords : Fish processing ; Ceramic membranes ; Ultrafiltration ; Fouling; Cleaning 


\section{Introduction}

As in most wastewaters from the food industry, the contaminants present in wastewaters from fish processing are a mixture of substances, mostly organic in nature. The composition of these effluents is varied as it is produced by different sources, including water from cleaning and washing of raw materials, fish treatment (e.g. boiling waters, blood water, process waters from drying and evaporation) and waste management. The discharge limits for fish processing effluents are covered by several international guidelines which are progressively incorporated to the national regulations. In the case of the United States, the Environment Protection Agency (EPA) establishes the quality standards for fisheries wastewaters depending on the type of processing and the fish species being processed. For instance, effluents from fish meal processing should not exceed a $B^{\circ O D_{5}}$ above $7 \mathrm{~kg} \mathrm{O}_{2}$ / ton raw fish [1]. In the case of the European Union, there are a wide range of regulations and standards controlling the fisheries wastewaters, both inside and outside the EU. For instance, the EU Urban Waste Water Treatment Directive 91/272/EEC [2] gives general guidelines for both urban sewage and industrial waters, which are completed by the different national regulations.

Among the different technologies that can be applied for the treatment of these wastewaters, the capability of membrane techniques highlights, aiming to produce dischargeable water, complying with the increasingly strict legislation on industrial pollution. Membrane separation processes are increasingly used in the fields of chemical engineering, effluent treatment processes and separation/purification of biotechnology products. In all membrane separation processes, a feed solution is separated into a stream which passes through the membrane, referred to as permeate, and a fraction which is retained or the retentate.

Membrane separation technologies are potentially able to reduce the organic load of polluted effluents or process waters from fish industry, rendering a final filtrate whose discharge has a minimal impact on the environment. The use of membranes for the treatment of process and waste waters from marine sources is extensively reviewed by Afonso and Bórquez [3] and Massé et al. [4]. They are considered among the Best Available Technologies (BAT), following the EU environmental recommendations [5], since they present high efficiency (in terms of COD removal and selectivity) and can be carried out under mild conditions.

Interestingly, some authors have also studied the recovery of valuable molecules from these effluents, such as lipids or proteins, able to be incorporated into the formulation of animal or human feedstuffs. In this regard, it is of special interest the combination of enzymatic hydrolysis to membrane separations. For instance, ultrafiltration is widely used to fractionate the peptidic fractions resulting from an enzyme hydrolysis. A complete review on the use of membrane separation techniques in the fields of peptide or lipid fractionation, aroma upgrading and recovery of carbohydrates from marine sources is provided by Bourseau et al. [6].

With respect to the membrane material, ceramic membranes take advantage over other polymeric ones because of their high mechanical and chemical resistance. Unfortunately, the operation of ceramic membranes (as also occurs with polymeric ones) is constrained by fouling phenomena. This term refers to the deposition of material caused by the physical or chemical interactions between the membrane and various components present in the feed solution $[7,8]$. Early empirical models regarding fouling mechanisms were developed by Hermia [9] for dead-end filtration. These models were subsequently adapted to cross-flow systems by considering the intermolecular forces between the bulk solution and the particles deposited on the foulant layer, such as the electrical repulsion [10] or the dragging of deposited particles by the tangential flow [11]. The main, undesirably consequence of fouling is the reduction of permeate flux which, at some level, requires the interruption of the filtration 
operation in order to perform a cleaning procedure to restore the permeability of the membrane.

The purpose of this paper was to study the ultra and microfiltration of the press liquor originated from the compaction of sardine by-products, which is a common waste in the production of fish meal. First, membranes were characterised in terms of permeate flux as a function of both transmembrane pressure and time. Then, protein rejection and chemical oxygen demand (COD) removal were assessed in the course of the membrane operation. Finally, the efficiency of a 3-step cleaning procedure was evaluated by following the restoration of the water permeate flux.

\section{Materials and methods}

\subsection{Obtention of the fish press liquor}

Sardine by-products were provided by the fish canning company Saupiquet, located in Quimper (France). They were kept in ice during the transport and pressed the same day to minimise the spoilage of the raw material. The raw material presented a protein and lipid content of $16 \%$ and $17 \%$, respectively.

These by-products were pressed stepwise by means of a pilot prototype comprising a cutting machine provided with four circular blades, attached to a hydraulic press able to develop up to 150 bar. The compacting operation comprised 3 consecutive pressing steps, interspersed with two relaxation periods of $90 \mathrm{~s}$, where the piston stopped allowing the press liquor to drain. The liquor released in the course of the operation was collected inside a storage tank placed under the hydraulic press.

In order to remove the suspended particles able to clog the membrane devices, the press liquor was pumped through two filter cartridges in series (Dynamesh, PALL, Port Washington, New York, USA) of $465 \mu \mathrm{m}$ and $250 \mu \mathrm{m}$ rating size, each one providing a filtration area of $0.1 \mathrm{~m}^{2}$. This operation led to a departiculated juice with a reduced content in both protein (4\%) and lipids (1\%).

\subsection{Experimental set-up and procedure}

Three Membralox ceramic tubular membranes of, respectively, nominal pore size $50 \mathrm{~nm}, 200$ $\mathrm{nm}$ and $1.4 \mu \mathrm{m}$ (Pall, Port Washington, USA) were employed for the ultrafiltration tests. Each membrane presents a single channel of $7 \mathrm{~mm}$ diameter and $250 \mathrm{~mm}$ length, providing an overall filtration area of $0.005 \mathrm{~m}^{2}$. Both the $50 \mathrm{~nm}$ and $200 \mathrm{~nm}$ membranes present an active layer of zirconite, while that of the $1.4 \mu \mathrm{m}$ membrane was made of $\alpha$-alumina.

The ultrafiltration assays were undertaken at pilot scale by means of a Maxim UF/MF System from Pall (Port Washington, USA). The raw press liquor was transferred to a $10 \mathrm{~L}$ glass tank, equipped with a level indicator. The temperature of the feed was kept at $20^{\circ} \mathrm{C}$ by means of a cooling coil using glycol as refrigerant fluid.

The performance of each one of the tubular ceramic membranes was tested following the same procedure. First, the membranes were hydrated for 1 hour. At this point, the membrane permeability was determined with de-ionised water at $20^{\circ} \mathrm{C}$ by measuring the water flux against transmembrane pressure, which was set by acting on the retentate valve. Retentate flow was set at $350 \mathrm{~L} / \mathrm{h}$, corresponding to a crossflow velocity of $3.3 \mathrm{~m} / \mathrm{s}$, which ensures a turbulent flow regime. 
Then, calibration tests employing the press liquor consisted in the filtration of the $2 \mathrm{~L}$ of feed solution through the membrane with total recycle of both permeate and retentate to the feed tank. The flux of permeate was determined as a function of the transmembrane pressure, while the crossflow velocity was kept at $3.3 \mathrm{~m} / \mathrm{s}$.

In order to study the time evolution of permeate flux, proteins rejection and COD removal, $2 \mathrm{~L}$ of press liquor were filtered for $3 \mathrm{~h}$ at constant cross-flow velocity $(3.3 \mathrm{~m} / \mathrm{s})$ and transmembrane pressure (1.5 bar). Both retentate and permeate were recycled to the feed tank. After completing this operation, the water flux of the fouled membrane was determined.

\subsection{Cleaning protocol}

A 3-step cleaning treatment, involving an alkali, acid and disinfection stage, was applied to restore the initial water flux after the ultrafiltration operation. The complete cleaning sequence comprised the following steps:

- Initial rinse of the fouled membrane with water at room temperature and a cross-flow velocity of $3.3 \mathrm{~m} / \mathrm{s}$.

- Alkaline treatment with $20 \mathrm{~g} / \mathrm{L} ~ N a O H$ plus $2 \mathrm{~g} / \mathrm{L}$ SDS as surfactant agent. Temperature was set at $50^{\circ} \mathrm{C}$, transmembrane pressure was 1.5 bar and cross-flow velocity was $3.3 \mathrm{~m} / \mathrm{s}$. The total recirculation mode was followed for 30 minutes.

- Acid treatment with $0.5 \% \mathrm{w} / \mathrm{w}$ HNO3. Temperature was set at $50^{\circ} \mathrm{C}$, transmembrane pressure was 1.5 bar and cross-flow velocity was $3.3 \mathrm{~m} / \mathrm{s}$. The total recirculation mode was followed for 30 minutes.

- Final disinfection stage with a $\mathrm{NaClO}$ solution $(250 \mathrm{ppm} \mathrm{Cl}$ ) plus $0.5 \mathrm{~g} / \mathrm{L} \mathrm{NaOH}$ to rise the pH over 11 , since this prevents the corrosion of the steel elements and piping [12]. Temperature was set at $30^{\circ} \mathrm{C}$, transmembrane pressure was 1.5 bar and crossflow velocity was $3.3 \mathrm{~m} / \mathrm{s}$. The total recirculation mode was followed for 15 minutes.

After each stage, both ports were rinsed with water until neutrality of the streams and the water flux was determined to evaluate the efficiency of each particular cleaning agent.

\subsection{Biochemical analysis}

The content of protein was determined by the Kjeldahl method, employing a conversion factor of 6.25 (equivalent to 0.16 grams of nitrogen per gram of protein), which is commonly used in food applications [13]. With regard to the content of lipids, they were extracted from the sample according to the method described by Folch et al. [14].

The concentration of soluble protein in the permeate samples was very low to be precisely determined by the standard Kjeldahl method. The bicinchonicic acid (BCA) method [15] was employed instead. To this purpose, the samples were diluted so they would fall within the range of $0-25 \mu \mathrm{g} / 100 \mu \mathrm{L}$. The diluted samples were transferred to a microplate and then mixed with the BCA working reagents (BCA Micro Protein Assay Kit, Pierce, Rockford, Illinois, USA) according to the experimental procedure. The mixture was incubated at $37^{\circ} \mathrm{C}$ for 30 minutes in order to develop an intense purple colour. The microplate was then placed in a spectrophotometer microplate reader (Anthos Labtec HT3, Salzburg, Austria) and the absorbance was read at $562 \mathrm{~nm}$. 
The chemical oxygen demand (COD) of the raw and filtered liquors were determined according to the Open Reflux Method [16], which employs dichromate as oxidant agent. The average result of COD was $125000 \mathrm{mg} \mathrm{O}_{2} / \mathrm{L}$ for the raw press liquor and $118000 \mathrm{mg} \mathrm{O}_{2} / \mathrm{L}$ for the departiculated stream entering the ultrafiltrafiltration unit. This value is similar to that estimated by Guerrero et al. [17] for the range of COD of the effluents resulting from a fish meal plant $\left(30-120 \mathrm{~g} \mathrm{O}_{2} / \mathrm{L}\right)$.

\section{Results and discussion}

\subsection{Permeate flux of water and fish press liquor against transmembrane pressure}

The permeability of the three unfouled membranes assayed $(50 \mathrm{~nm}, 200 \mathrm{~nm}$ and $1.4 \mu \mathrm{m}$ ) was determined by linear regression of the water flux (J) against the transmembrane pressure (TMP), as shown in the Fig. 1. The experimental data were fitted to a straight line by forcing a null intercept. The inverse of the slope of each straight line, which represents the intrinsic resistance $\left(R_{M}\right)$, was calculated for each membrane, according to Eq. (1):

$$
\mathrm{J}=\frac{\mathrm{TMP}}{\mathrm{R}_{\mathrm{M}}}
$$

The values calculated for $R_{M}$ are listed in Table 1 . It can be seen that the resistance decreases with the membrane pore size from $2.50 \cdot 10^{-3}$ to $5.04 \cdot 10^{-4} \mathrm{bar} \cdot \mathrm{m}^{2} \cdot \mathrm{h} / \mathrm{L}$ when comparing the valued at $50 \mathrm{~nm}$ and $1.4 \mu \mathrm{m}$.

In Fig. 2, it is shown the relationship between the flux of permeate and the transmembrane pressure for the press liquor. According to the resistances-in-series model, the flux of permeate increases linearly with pressure up to a certain extent and then increases (with a decreasing slope) until attaining a plateau where the flux $\left(\mathrm{J}_{\max }\right)$ is independent of the transmembrane pressure. Therefore, the flux of permeate $(\mathrm{J})$ can be related to the transmembrane pressure (TMP) according to Eq. (2):

$$
\mathrm{J}=\frac{\mathrm{TMP}}{\alpha+\beta \cdot \mathrm{TMP}}
$$

where $\alpha$ stands for the resistance at low values of transmembrane pressure, i.e. in the linear region. This parameter $\alpha$ is related to the intrinsic membrane resistance and any initial resistance due to fouling. The second term in the denominator ( $\beta$.TMP) represents the resistance of the gel polarisation layer, which is assumed to be proportional to the applied transmembrane pressure TMP with a proportionality constant $\beta$. The value of $J_{\max }$ can be easily obtained as $1 / \beta$ by assuming a high transmembrane pressure which would make $\alpha$ negligible.

Table 1 shows the values of $\alpha$ and $\beta$ obtained by non-linear regression as well as the values of the steady flux $\left(J_{\max }\right)$ for the three ceramic membranes. The curves predicted are represented by the solid lines in Fig. 2, while the dotted lines stand for the water flux for each membrane. It can be seen that the values of $\alpha$ were many times higher than the respective values of membrane intrinsic resistances $R_{M}$. The largest difference between both values was observed for the $\alpha$-alumina membrane $(1.4 \mu \mathrm{m})$. The small interval of variation registered for the parameter $\beta$, which ranges from $1.90 \cdot 10^{-2}$ to $1.58 \cdot 10^{-2} \mathrm{~m}^{2} \cdot \mathrm{h} / \mathrm{L}$, suggested that this value is not significantly affected by the membrane pore size.

\subsection{Evolution of the flux of permeate}

Considering the filtration of fish press liquor, Fig. 3 shows the time evolution of the flux of permeate for the three assayed membranes. The flux of permeate undergoes a steep decline 
during the first hour of operation. Then, the permeate flux decreases at a lower rate, reaching a steady state where the permeate flux remains constant in time. This behaviour can be explained by the model developed by Suki et al. [11], represented by the solid lines in Fig. 3 and expressed in Eq. (3):

$$
\mathrm{J}=\frac{\mathrm{J}_{0}}{1+\left(\frac{\mathrm{J}_{0}-\mathrm{J}_{\infty}}{\mathrm{J}_{\infty}}\right) \cdot(1-\exp (-\mathrm{k} \cdot \mathrm{t}))}
$$

Suki's approach relies on the resistances-in-series model, in which the resistance due to fouling is assumed to be time dependent according to a first-order kinetics with a constant $\mathrm{k}$. While $\mathrm{J}_{0}$ stands for the initial flux, $\mathrm{J}_{\infty}$ represents the flux steady flux reached at longer times. The fouling resistance is considered to be proportional to the amount of matter deposited on the membrane, which increases with time until reaching a value of equilibrium, where the deposition of foulants is balanced by the tangential migration of particles dragged by the retentate flow.

The parameters for Suki's model, summarised in Table 3, were estimated by non-linear regression and a satisfactory fit was obtained as reflected by the coefficients of determination $r^{2}$. Table 2 lists the values of initial flux of permeate $\left(\mathrm{J}_{0}\right)$. In the case of the zirconite membranes (50 nm and $200 \mathrm{~nm}$ ), this value increased with the nominal pore size. However, the $1.4 \mu \mathrm{m}$ membrane, despite its larger pore size, presented the lowest value of initial flux of permeate, $\mathrm{J}_{0}=26.7 \mathrm{~L} /\left(\mathrm{m}^{2} \cdot \mathrm{h}\right)$, which means that the initial resistance provided by this membrane against the passage of press liquor was the largest. This is in accordance with the calibration curves shown in Fig. 2, which show that the values of initial flux of permeate, at any value of transmembrane pressure, were lower for the $\alpha$-alumina membrane. Similarly, the lowest value of steady flux of permeate was obtained for the $\alpha$-alumina membrane, $J_{\infty}=$ $20.35 \mathrm{~L} /\left(\mathrm{m}^{2} \cdot \mathrm{h}\right)$, while the steady flux calculated for the $50 \mathrm{~nm}$ and $200 \mathrm{~nm}$ membranes were larger and increased with the nominal pore size.

Considering that the fluidodynamic conditions and the feed solution were the same, these differences of the $1.4 \mu \mathrm{m}$ membrane with respect to the other membranes of lower pore size may only be attributable to the material of its active layer. The active filtration layer for the membrane of $1.4 \mu \mathrm{m}$ is made of $\alpha$-alumina, instead of zirconite. In ceramic materials, the surface is covered by hydroxyl species which are partially ionised depending on the $\mathrm{pH}$ of the feed solution and the point of zero charge of the material. The point of zero charge (pzc) is the $\mathrm{pH}$ at which the surface carries no net electrical charge. At pHs above point of zero charge, the negative charged species are predominant; otherwise the ionisation equilibrium is displaced towards the formation of positive species.

In our case, the point of zero charge for the a-alumina oxides is $8-9$ [18], while zirconium oxide membranes present a value of pzc close to neutrality [19]. This means that, considering the $\mathrm{pH}$ of the feed solution $(6.8-7.2)$, the membrane surface for the $1.4 \mu \mathrm{m}$ membrane would acquire a net negative charge during the ultrafiltration, while the membranes from zirconite were charged positively. This charge distribution is responsible for the adsorption or repulsion of fouling solutes (mostly proteins) on the membrane surface or on the pore walls, which could explain the differences observed in the behaviour of the flux of permeate between zirconite and $\alpha$-alumina membranes. This fact was confirmed by other studies found in the literature. Carić et al. [20] studied the static adsorption of whey proteins on ceramic membranes, comparing a $50 \mathrm{~nm}$ pore size zirconite membrane with a $200 \mathrm{~nm}$ alumina membrane. It was found that the rate of adsorption of proteins on the membrane surface was higher for the alumina membrane, while in $50 \mathrm{~nm}$ zirconite membranes the hydraulic resistance was controlled by the cake formation.

With respect to $k$, the parameter which controls the fouling build-up, it is similar for both zirconite membranes (50 nm and $200 \mathrm{~nm}$ ), which suggests a similar pattern of interactions 
between membrane and foulants for both modules. Regarding the $1.4 \mu \mathrm{m}$ membrane, the kinetic constant $\mathrm{k}$ was found to be $31 \%$ lower than that observed for both zirconite membranes, which implies that the fouling deposit grows at s lower rate.

\subsection{Protein rejection and COD of the permeate}

Four samples of fish press liquor permeate were collected after 30 minutes, 1, 2 and 3 hours of total recycle operation. The protein content in the retentate remained approximately constant in the course of the operation $(44.1 \mathrm{mg} / \mathrm{mL})$, but not the concentration of proteins in the permeate stream, due to the fouling phenomena which limits the passage of feed solutes through the membrane. The percentage of protein rejection was evaluated at each time according to the Eq. (4):

$$
\text { Pr otein rejection }=\left(1-\frac{C_{P}}{C_{R}}\right) \cdot 100
$$

where $C_{P}$ and $C_{R}$ are the concentration of protein in the permeate and retentate, respectively. The Figure $4 a$ shows the values of protein rejection in the course of the ultrafiltration for the three membranes. The membrane of $50 \mathrm{~nm}$ presented the highest values of protein rejection, with an average protein rejection of $85 \%$. This could be attributable to its lower size, which results in higher solute retention due to steric impediments. It is followed by the membrane of $200 \mathrm{~nm}$, whose average protein rejection was $78 \%$. The a-alumina membrane, despite its larger pore size, presented an average protein rejection (77\%) similar to that obtained for the membrane of $200 \mathrm{~nm}$. These results agree with the assumption of a higher protein adsorption on the $\alpha$-alumina membrane mentioned above.

Concerning the evolution of the protein rejection in time, it slightly decreased in the course of the ultrafiltration for the membrane of $50 \mathrm{~nm}$. Both $200 \mathrm{~nm}$ and $1.4 \mu \mathrm{m}$ membranes exhibited an initial decrease of the protein rejection and a subsequent increase. These results are in accordance to those of Marshall et al. [21], who reported a similar trend during the ultrafiltration of $\beta$-globuline with a ceramic membrane of $50 \mathrm{~nm}$ and a crossflow velocity of 3 $\mathrm{m} / \mathrm{s}$. To this regard, Hilal et al. [22] suggested that fouling agents, mainly proteins, tend to absorb initially onto the charged residues situated all across the membrane surface or within the pore walls. As these active points are neutralised by the foulant particles, the free charge of the membrane decreases, thus decreasing the protein rejection by electrostatic repulsion. Once all the free charges have been neutralised by the deposition of foulant particles, the protein rejection should be governed exclusively by the steric effects.

Similarly to the protein content, the chemical oxygen demand (COD) of the permeate was measured at 30 minutes, 1,2 and 3 hours of total recycle operation. The COD removal efficiency (CODR) was then calculated by the Eq. (5):

$$
\text { COD removal }=\left(1-\frac{\mathrm{COD}_{\mathrm{P}}}{\mathrm{COD}_{\mathrm{R}}}\right) \cdot 100
$$

where $\mathrm{COD}_{\mathrm{P}}$ and $\mathrm{COD}_{\mathrm{R}}$ represent the $\mathrm{COD}$ of the permeate and the concentrate streams at a certain time, respectively. Owing to the operating mode, the latter is assumed to remain constant in time and equal to the initial COD of the feed solution (i.e. the de-particulated press liquor exiting the second filter cartridge), which presented an average value of 118000 $\mathrm{mg} \mathrm{O}_{2} / \mathrm{L}$.

Fig. $4 \mathrm{~b}$ shows the time evolution of the COD removal for each membrane. The observed values of COD of the permeate streams did not present any significant trend in time during the operation, oscillating around an average value $\left(16250,16425\right.$ and $19075 \mathrm{mg} \mathrm{O}_{2} / \mathrm{L}$ for the $50 \mathrm{~nm}, 200 \mathrm{~nm}$ and $1.4 \mu \mathrm{m}$, respectively). Both the membranes of $50 \mathrm{~nm}$ and $200 \mathrm{~nm}$ achieved an average COD removal efficiency of $86 \%$, followed by the membrane of $1.4 \mu \mathrm{m}$ (84\%). The lower COD removal efficiency observed in the membrane of $1.4 \mu \mathrm{m}$ was 
attributed to its larger nominal pore size and lower protein rejection. Nevertheless, the slight difference in COD removal observed between this membrane and the zirconite membranes of lower pore size may suggest larger interactions between solutes and the membrane active layer in the $\alpha$-alumina membrane.

\subsection{Cleaning treatment}

Once the 3-hour ultrafiltration assays were finished, the fouled membrane was cleaned following the 3-stage protocol described previously. After each chemical cleaning stage, the membrane was rinsed with demineralised water until neutrality of the permeate stream, and then its water flux was measured. The restore of the membrane permeability throughout the cleaning treatment is evidenced by the Fig. 5, where the flux of water permeating the membrane is plotted against transmembrane pressure (TMP). The slope of the regression lines (i.e. the water permeability) increases after each cleaning stage until attaining the permeability of the unfouled membrane (represented by the dotted line).

As shown in Table 3, the cleaning efficiency was assessed by the evolution of the total and fouling resistances, which permitted to evaluate a cleaning efficiency index for each cleaning stage. The total hydraulic resistance $\left(R_{T}\right)$ provided by the membranes after each cleaning step was determined as the inverse of the slope of the water flux against the transmembrane pressure, according to Eq. (1). Assuming that the total resistance of the fouled membrane is the contribution of the intrinsic membrane resistance $\left(R_{M}\right)$ and that provided by the remaining fouling deposits $\left(R_{F}\right)$, the latter could be evaluated by Eq. (6):

$$
\mathrm{R}_{\mathrm{F}}=\mathrm{R}_{\mathrm{T}}-\mathrm{R}_{\mathrm{M}}
$$

With regard to the cleaning efficiency index, which accounts for the contribution of an i-th cleaning stage in the total recovery of the water flux of a fouled membrane, it was defined as a function of the hydraulic resistances by means of Eq. (7):

$$
E=\frac{R_{i-1}-R_{i}}{R_{0}-R_{M}} \cdot 100
$$

where $R_{i-1}$ and $R_{i}$ stand for the hydraulic resistance of the membrane before and after the $i$-th cleaning step, $R_{M}$ is the intrinsic membrane resistance and $R_{0}$ represents the initial resistance of the fouled membrane (i.e. only rinsed with water after the ultrafiltration). The global cleaning efficiency indices, calculated as the sum of the cleaning indices for each cleaning stage, were close to $100 \%$ for the three membranes.

With regard to the alkali stage, it was efficient to restore the membrane permeability, being responsible to a large extent (up to $90 \%$ for the $50 \mathrm{~nm}$ membrane) of the overall recovery of the membrane flux. Indeed, an initial cleaning stage with alkali has proved to be very effective since it is able to hydrolyse, solubilise and remove the protein deposits [23]. On the contrary, the acid stage exhibited a detrimental effect on the permeability of the $50 \mathrm{~nm}$ membrane, since the hydraulic resistance measured after this treatment was $27 \%$ higher than that obtained after the alkali stage. For the other membranes, its effect on the water flux recovery was weak, with cleaning efficiencies of $16 \%$ and $3 \%$, respectively. These results agree with those reported previously by some authors [24-26]. According to Blanpain-Avent et al. [26] this poor cleaning efficiency was likely to be due to physico-chemical interactions between nitric acid and the fouling deposits remaining on the membrane surface after the alkaline cleaning. Vaïsänen et al. [25] assumed that these deposits could form a gel-like structure which is resistant to cleaning. In contrast, Barlett et al. [23] reported that a cleaning stage with $0.3 \% \mathrm{w} / \mathrm{w} \mathrm{HNO}_{3}$ improved the results obtained by a previous $0.2 \% \mathrm{w} / \mathrm{w} \mathrm{NaOH}$ treatment in ceramic membranes fouled after milk ultrafiltration, since it was able to solubilise and remove the deposits of inorganic salts, such as calcium phosphate.

Finally, the disinfection stage with sodium hypochlorite was effective to restore the initial water flux of the three membranes studied. Besides its disinfecting action, due to the release 
of free Chlorine $\left(\mathrm{Cl}_{2}\right)$, the $\mathrm{NaOCl}$ can remove the organic material deposited on the membrane surface and within the pores [8]. This is owed to the oxidation of the organic compounds to other groups, such as aldehydes, ketones or carboxylic acids, which exhibit higher a hydrophilicity and thus, a lower adhesion to the membrane material.

\section{Conclusion}

Three ceramic membranes of average pore sizes of $50 \mathrm{~nm}, 200 \mathrm{~nm}$ and $1.4 \mu \mathrm{m}$ were tested in terms of hydrodynamic behaviour, organic load of the permeate and efficiency of an alkaliacid-oxidant cleaning sequence. The observed flux in the course of the membrane filtration was fitted to a cake forming-based model developed by Suki et al. [11], with a good degree of correlation between the experimental data and the predicted model.

The $200 \mathrm{~nm}$ membrane presented the higher average flux at steady state, higher than 25 $\mathrm{L} /\left(\mathrm{m}^{2} \cdot \mathrm{h}\right)$, with a moderate relative flux decline. This value was higher than that observed for the membrane of $1.4 \mu \mathrm{m}$, which was $20 \mathrm{~L} /\left(\mathrm{m}^{2} \cdot \mathrm{h}\right)$, probably attributed to the different composition of its active layer.

Comparing the average values of protein rejection, the membrane of $50 \mathrm{~nm}$ presented the largest rejection (85\%), followed by the membrane of $200 \mathrm{~nm}(78 \%)$, which was expected owing to their pore sizes. Despite its larger pore size, the membrane of $\alpha$-alumina presented an average protein rejection (77\%) similar to the membrane of $200 \mathrm{~nm}$.

Both the membrane of $50 \mathrm{~nm}$ and that of $200 \mathrm{~nm}$ presented similar values of average COD removal (around 86\%). The permeate streams originating from the three membranes studied presented average values of COD (ranging from 16250 to $19075 \mathrm{mg} \mathrm{O}_{2} / \mathrm{L}$ ) below the discharge limits imposed for sardine processing by the EPA regulations.

Regarding to the cleaning treatment, the complete cleaning sequence comprising an alkali, an acid and a final disinfection stage restored completely the initial permeability of the three membranes. Nevertheless, it was noticed that the effect of the acid stage with nitric acid was not significant or even detrimental to the cleaning efficiency (e.g. 27\% increase of the hydraulic resistance of the $50 \mathrm{~nm}$ after the acid step), which suggested its removal from the cleaning protocol.

\section{Acknowledgements}

This work was funded by the projects LIFE05 ENV/E/000267 from the European Commision and CTQ2008-02978 from the Spanish Ministry of Science and Innovation.

\section{References}

[1] J.F. González, Wastewater treatment in the fishery industry, FAO Fisheries Department, Rome, 1996.

[2] EU Council, EU Council Directive 91/271/EEC concerning urban waste water treatment. European Communities Publication, Brussels, 1991.

[3] M.D. Afonso, R. Bórquez, Review of the treatment of seafood processing wastewaters and recovery of proteins therein by membrane separation processes-prospects of the ultrafiltration of wastewaters from the fish meal industry, Desalination 142 (2002) 29-45. 
[4] A. Massé, L.Vandanjon, P. Jaouen, J. Dumay, E. Kéchaou, P. Bourseau, Upgrading and pollution reduction of fish industry process-waters by membrane technology, in: J. -P. Bergé (ed.), Added Value to Fishery Wastes, Transworld Research Network, Kerala, 2008, pp.81100.

[5] EU Commission, Integrated pollution, prevention and control. Reference document on Best Available Techniques (BAT) in the slaughterhouses and animal by-products industries, European Commission Publication, Brussels, 2005.

[6] P. Bourseau, A. Chabeaud, L. Vandajon, A. Massé, P. Jaoen, J. Fleurence, J.-P. Bergé, in: J.-P. Bergé (ed.), Added Value to Fishery Wastes, Transworld Research Network, Kerala, 2008, pp. 239-252.

[7] L.J. Zeman, A. Zydney, Microfiltration and Ultrafiltration: Principles and Applications, Marcel Dekker, New York, 1996.

[8] M. Cheryan, Ultrafiltration and Microfiltration Handbook, Technomic Publishers, Lancaster, 1998

[9] J. Hermia, Constant pressure blocking filtration laws: Application to power-law nonNewtonian fluids, Trans. Inst. Chem. Eng. 60(1982) 183-187.

[10] R.D. Cohen, R.F. Probstein, Colloidal fouling of reverse osmosis membranes, J. Colloid Interface Sci. 144(1986) 194-207.

[11] A. Suki, A.G. Fane, J.D. Fell, Flux decline in protein ultrafiltration, J. Membr. Sci. 21(1984) 269-283.

[12] G. Daufin, U. Merin, J.P. Labbe, A. Quemerais, F.L. Kerhervé, Cleaning of inorganic membranes after whey and milk ultrafiltration, Biotechnol. Bioeng. 38(1991) 82-89.

[13] J. Adler-Nissen, Enzymic hydrolysis of food proteins, Elsevier Applied Science Publishers LTD, London, 1986.

[14] J. Folch, M. Lees, G.H. Sloan-Standley, A simple method for the isolation and purification of total lipids from animal tissues, J. Biol. Chem. 226(1957) 497-509.

[15] P.K. Smith, R.I. Krohn, G.T. Hermanson, A.K. Mallia, F.H. Gartner, M.D. Provenzano, E.K. Fujimoto, N.M. Goeke, B.J. Olson, D.C. Klenk, Measurement of protein using Bicinchoninic Acid, Anal. Biochem. 150(1985) 76-85.

[16] L.S. Clescerl, A.E. Greenberg, A.D. Eaton, Standard methods for examination of water \& wastewater, 20th ed., American Public Health Association, Washington, 2005.

[17] L. Guerrero, F. Omil, R. Méndez, J.M. Lema, Protein recovery during the overall treatment of wastewaters from fish-meal factories, Biores. Technol. 63(1998) 221-229.

[18] J.P. Brunelle, Preparation of catalyst by metallic complex adsorption on mineral oxides, Pure Appl. Chem. 50(1978) 1211-1229.

[19] M. Kosmulski, Chemical properties of material surfaces, Marcel Dekker Inc., New York, 2001.

[20] M.Đ. Carić, S.D. Milanović, D.M. Krstić, M.N. Tekić, Fouling of inorganic membranes by adsorption of whey proteins, J. Membr. Sci. 165(2000) 83-88.

[21] A.D. Marshall, P.A. Munro, G. Trägårdh, Influence of permeate flux on fouling during the microfiltration of $\beta$-globulina solutions under cross-flow conditions, J. Membr. Sci. 130(1997) 23-30.

[22] N. Hilal, O. Ogunbiyi, N. Miles, R. Nigmatullin, Methods employed for control of fouling in MF and UF membranes: a comprehensive review, Sep. Sci. Technol. 40(2005) 1957-2005.

[23] M. Bartlett, M.R. Bird, J.A. Howell, An experimental study for the development of a qualitative membrane cleaning model, J. Membr. Sci. 105(1995) 147-157.

[24] A. Weis, M.R. Bird, The influence of multiple fouling and cleaning cycles upon the membrane processing of lignosulphonates, Food Bioprod. Proc. 79 (2001) 184-187.

[25] P. Väinäsen, M.R. Bird, M. Nyström, Treatment of UF membranes with simple and formulated cleaning agents, Food Bioprod. Proc. 80(2002) 98-108.

[26] P. Blanpain-Avet, J.F. Migdal, T. Bénézech, The effect of multiple fouling and cleaning cycles on tubular ceramic microfiltration membrane fouled with a whey protein concentrate: membrane performance and cleaning efficiency, Food Bioprod. Proc. 82(2004) 231-243. 
Table 1. Parameters estimated for the modeling of permeate flux of water and fish press liquor against transmembrane pressure

\begin{tabular}{|c|c|c|c|c|}
\hline Membrane & $R_{M}\left(\right.$ bar $\left.m^{2} h / L\right)$ & $a\left(\right.$ bar $\left.m^{2} h / L\right)$ & $\beta\left(m^{2} h / L\right)$ & $J_{\max }\left(L /\left(m^{2} h\right)\right)$ \\
\hline $50 \mathrm{~nm}$ & $2.50 \times 10^{-3}$ & $7.97 \times 10^{-3}$ & $1.90 \times 10^{-2}$ & 52.63 \\
\hline $200 \mathrm{~nm}$ & $1.52 \times 10^{-3}$ & $1.59 \times 10^{-2}$ & $1.83 \times 10^{-2}$ & 54.70 \\
\hline $1.4 \mu \mathrm{m}$ & $5.04 \times 10^{-4}$ & $2.22 \times 10^{-2}$ & $1.58 \times 10^{-2}$ & 63.29 \\
\hline
\end{tabular}

Table 2. Parameters estimated for the modelling of the time evolution of permeate flux of fish press liquor.

\begin{tabular}{lllll}
\hline Membrane & $J_{0}\left(\mathbf{L} /\left(\mathbf{m}^{2} \mathbf{h}\right)\right)$ & $J_{0}\left(\mathbf{L} /\left(\mathbf{m}^{2} \mathbf{h}\right)\right)$ & $\boldsymbol{k}\left(\mathbf{h}^{-\mathbf{1}}\right) \boldsymbol{r}^{\mathbf{2}}$ \\
\hline $50 \mathrm{~nm}$ & 33.69 & 23.50 & 2.15 & 0.9007 \\
$200 \mathrm{~nm}$ & 38.74 & 25.82 & 2.20 & 0.9417 \\
$1.4 \mu \mathrm{m}$ & 26.69 & 20.35 & 1.50 & 0.9314 \\
\hline
\end{tabular}


Table 3. Resistances and cleaning efficiency indices for the three studied membranes.

\begin{tabular}{|c|c|c|c|c|}
\hline Membrane & Cleaning stage & $R_{\mathrm{T}}\left(\right.$ bar $\left.\mathrm{m}^{2} \mathrm{~h} / \mathrm{L}\right)$ & $R_{\mathrm{F}}\left(\right.$ bar $\left.\mathrm{m}^{2} \mathrm{~h} / \mathrm{L}\right)$ & $E(\%)$ \\
\hline \multirow[t]{6}{*}{$50 \mathrm{~nm}$} & Unfouled & $2.50 \times 10^{-3}$ & - & - \\
\hline & After UF & $5.37 \times 10^{-3}$ & $2.87 \times 10^{-3}$ & - \\
\hline & $\mathrm{NaOH}$ & $2.80 \times 10^{-3}$ & $2.95 \times 10^{-4}$ & $89.72 \%$ \\
\hline & $\mathrm{HNO}_{3}$ & $3.56 \times 10^{-3}$ & $1.06 \times 10^{-3}$ & $-26.66 \%$ \\
\hline & $\mathrm{NaOCl}$ & $2.49 \times 10^{-3}$ & $6 \times 10^{-6}$ & $37.14 \%$ \\
\hline & Overall & - & - & $100.21 \%$ \\
\hline \multirow[t]{6}{*}{$200 \mathrm{~nm}$} & Unfouled & $1.52 \times 10^{-3}$ & - & - \\
\hline & After UF & $6.31 \times 10^{-3}$ & $4.79 \times 10^{-3}$ & - \\
\hline & $\mathrm{NaOH}$ & $4.20 \times 10^{-3}$ & $2.68 \times 10^{-3}$ & $44.05 \%$ \\
\hline & $\mathrm{HNO}_{3}$ & $3.43 \times 10^{-3}$ & $1.91 \times 10^{-3}$ & $16.08 \%$ \\
\hline & $\mathrm{NaOCl}$ & $1.53 \times 10^{-3}$ & $1.00 \times 10^{-5}$ & $39.67 \%$ \\
\hline & Overall & - & - & $99.79 \%$ \\
\hline \multirow[t]{6}{*}{$1.4 \mu \mathrm{m}$} & Unfouled & $5.10 \times 10^{-4}$ & - & - \\
\hline & After UF & $2.61 \times 10^{-3}$ & $2.10 \times 10^{-3}$ & - \\
\hline & $\mathrm{NaOH}$ & $1.50 \times 10^{-3}$ & $9.90 \times 10^{-4}$ & $52.86 \%$ \\
\hline & $\mathrm{HNO}_{3}$ & $1.43 \times 10^{-3}$ & $9.20 \times 10^{-4}$ & $-3.33 \%$ \\
\hline & $\mathrm{NaOCl}$ & $5.20 \times 10^{-4}$ & $1.00 \times 10^{-5}$ & $43.33 \%$ \\
\hline & Overall & - & - & $99.52 \%$ \\
\hline
\end{tabular}




\section{Figures}

Figure 1. Water flux against transmembrane pressure for the three membranes assayed

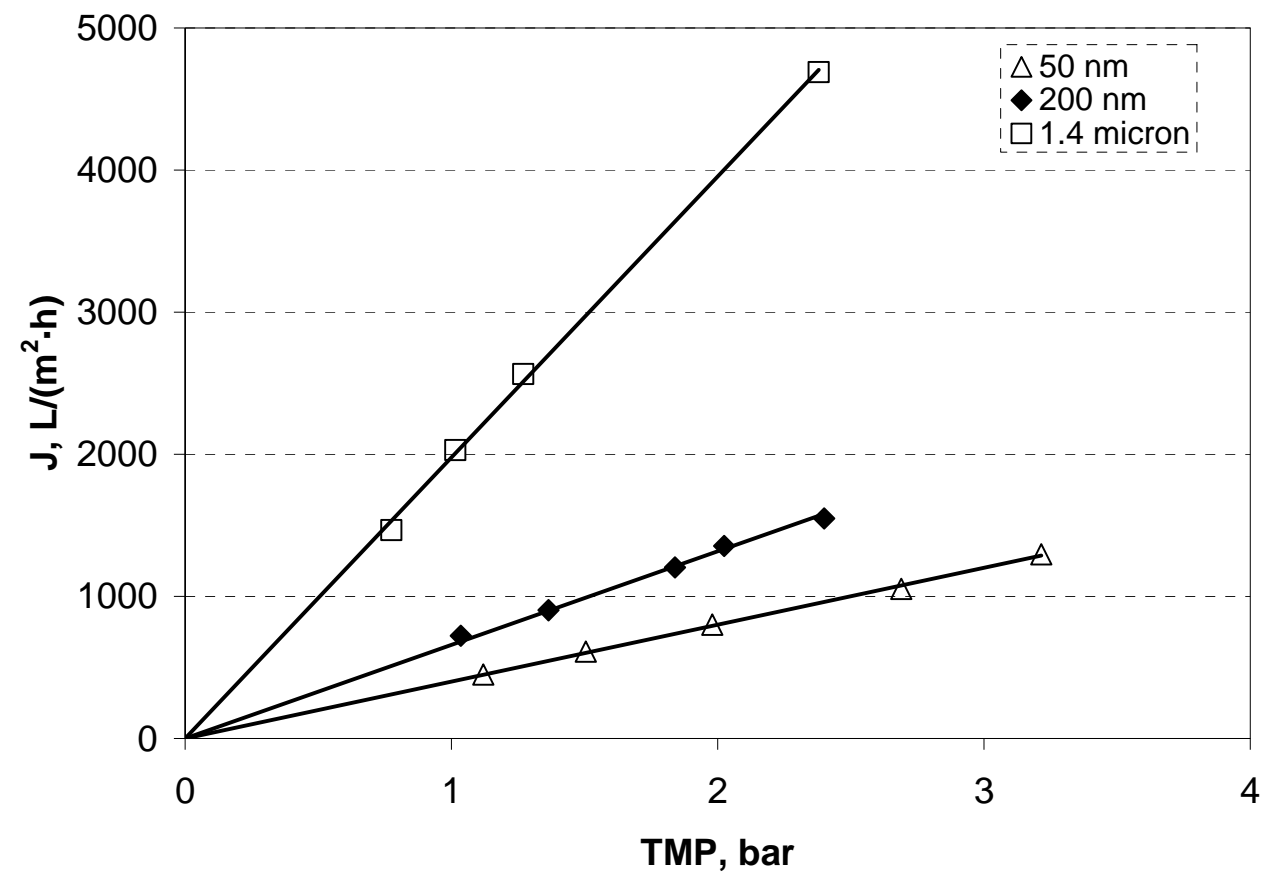


Figure 2. Permeate flux against transmembrane pressure for the three membranes assayed: (a) $50 \mathrm{~nm}$, (b) $200 \mathrm{~nm}$, (c) $1.4 \mu \mathrm{m}$
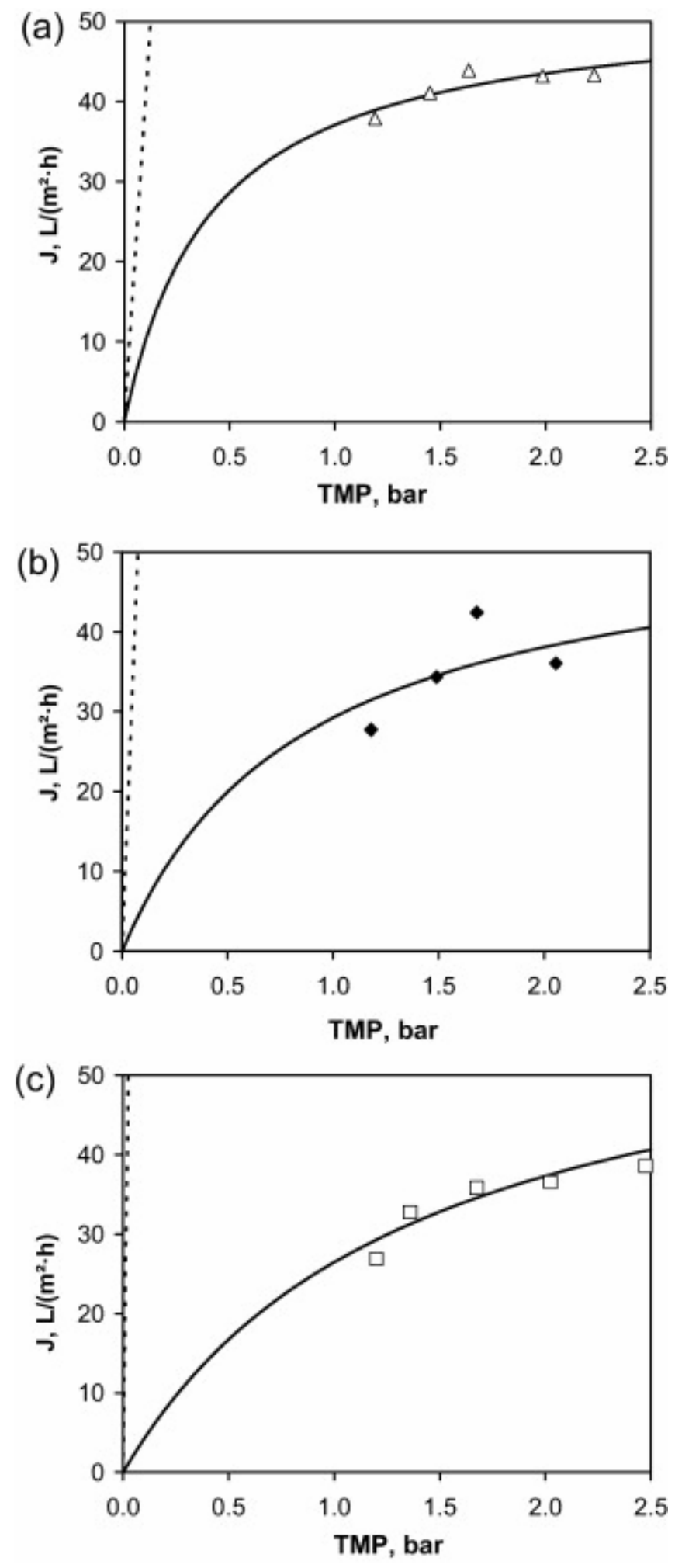
Figure 3. Time evolution of the permeate flux for the three membranes assayed

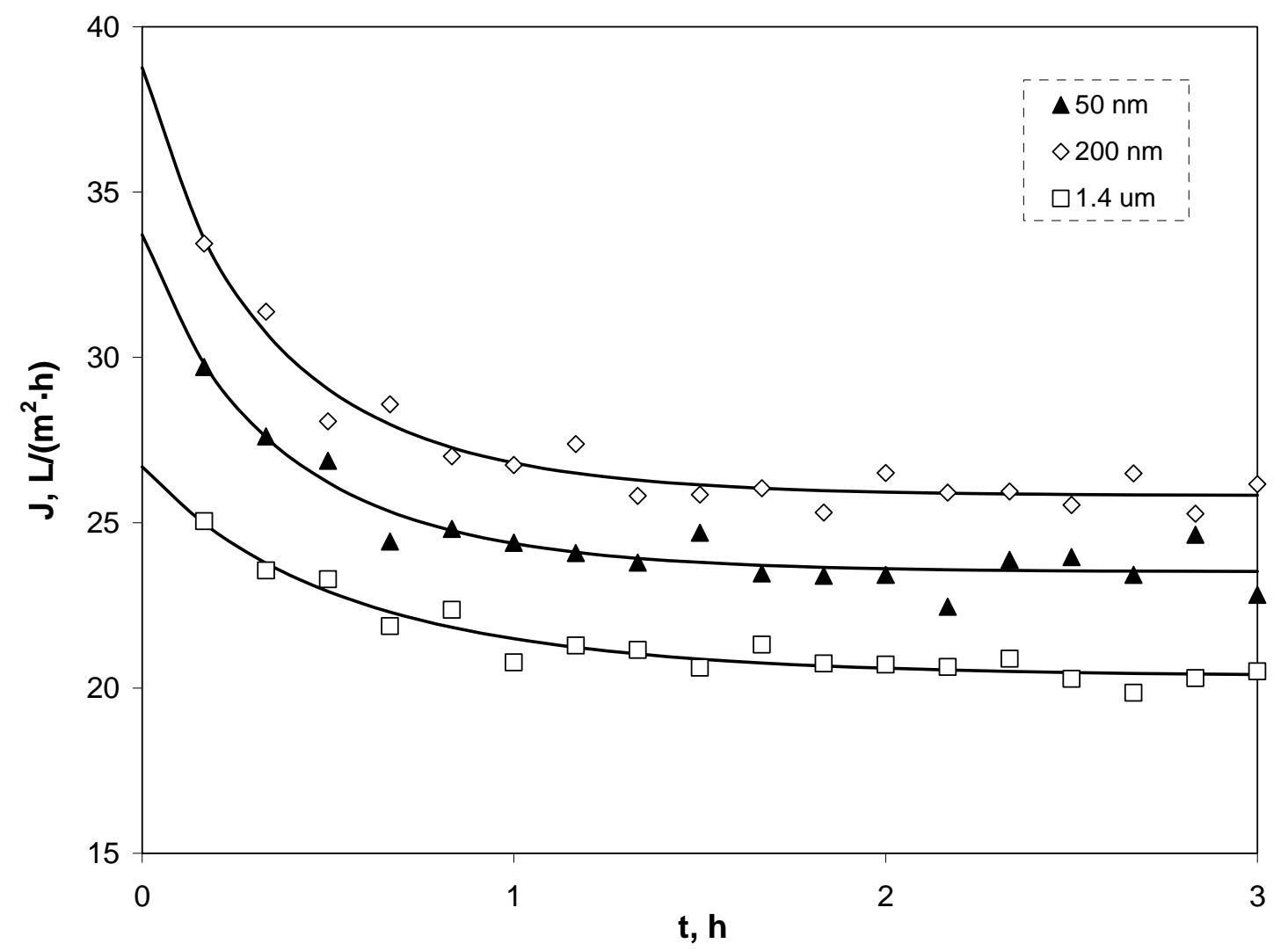


Figure 4. Time evolution of (a) protein rejection and (b) COD removal for the three membranes assayed

(a)

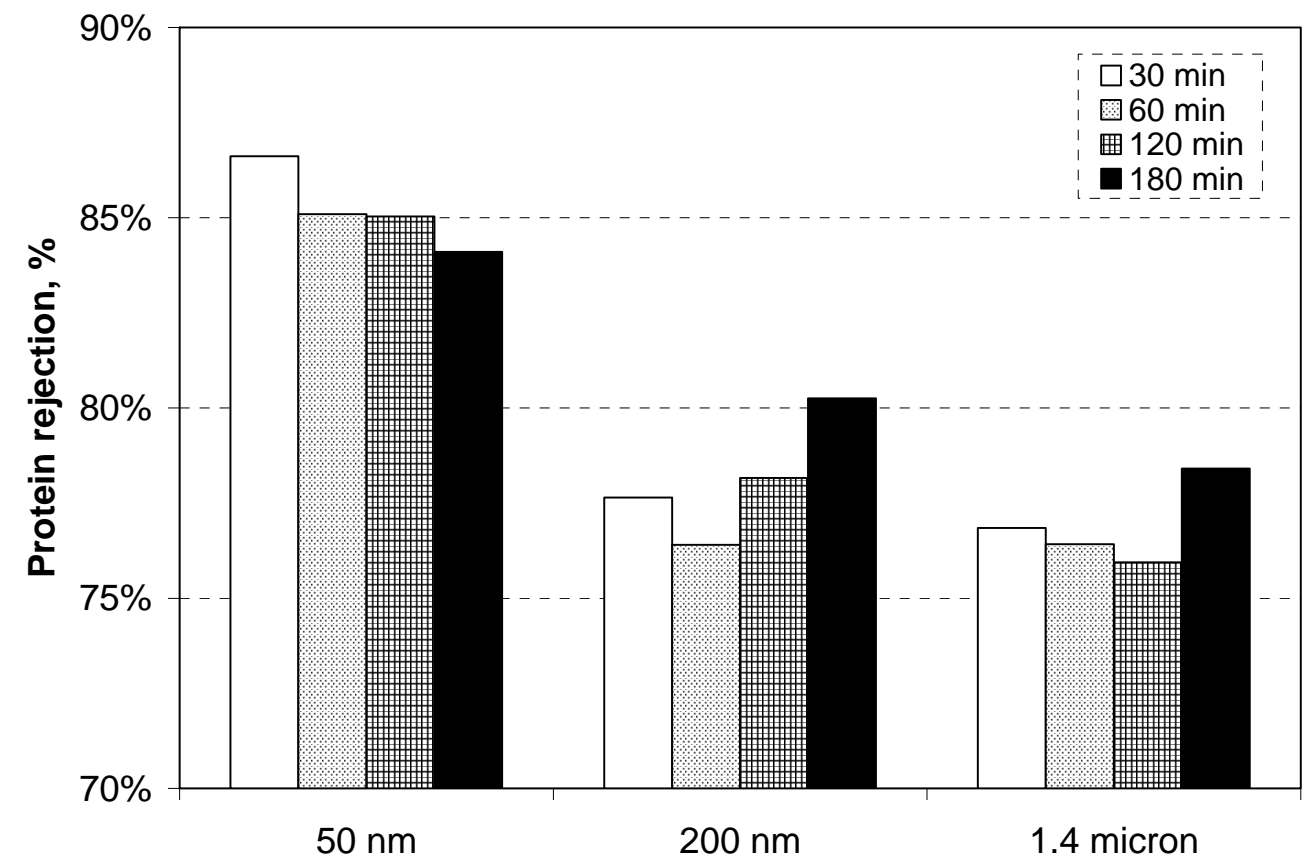

(b)

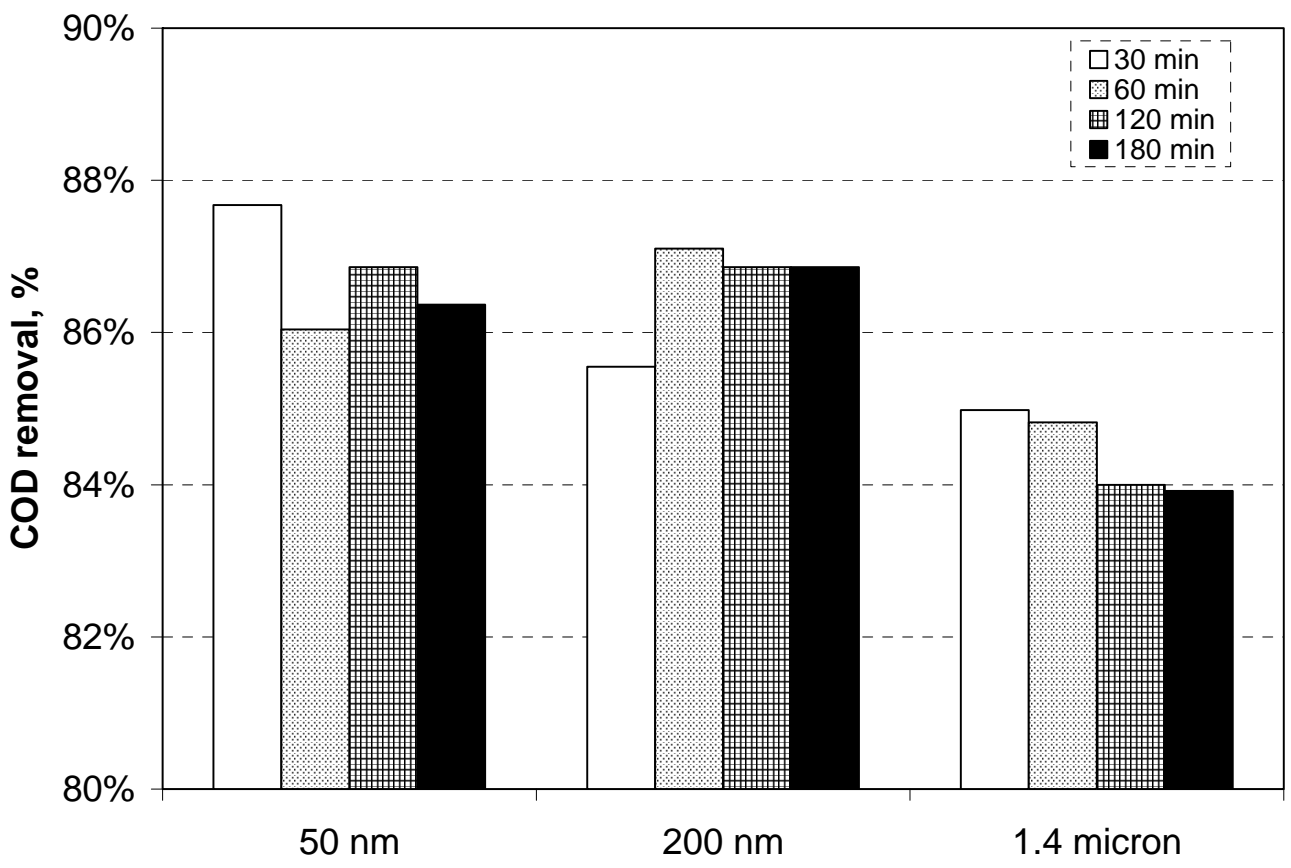


Figure 5. Water flux against transmembrane pressure after each cleaning step for the three membranes assayed: (a) $50 \mathrm{~nm}$, (b) $200 \mathrm{~nm}$, (c) $1.4 \mu \mathrm{m}$

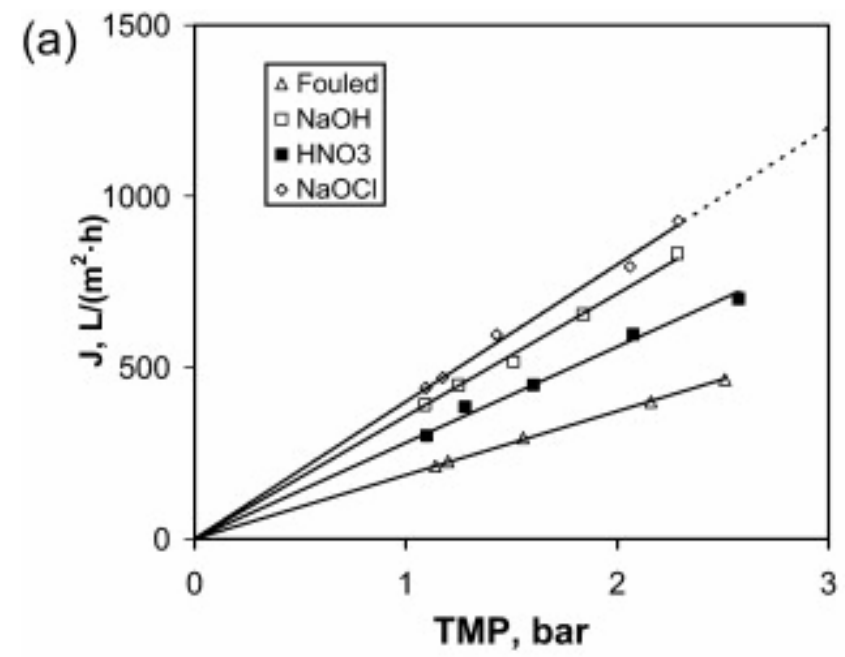

(b)

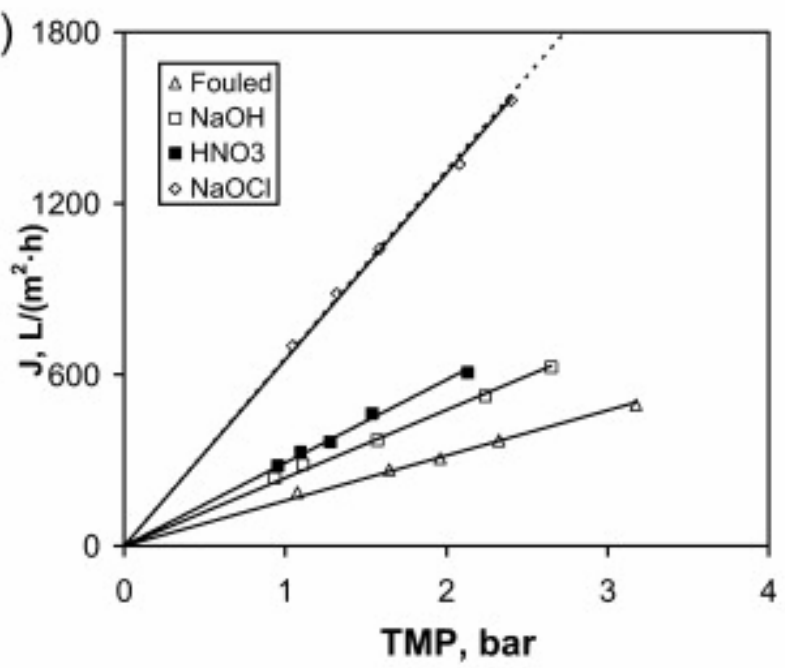

(c)

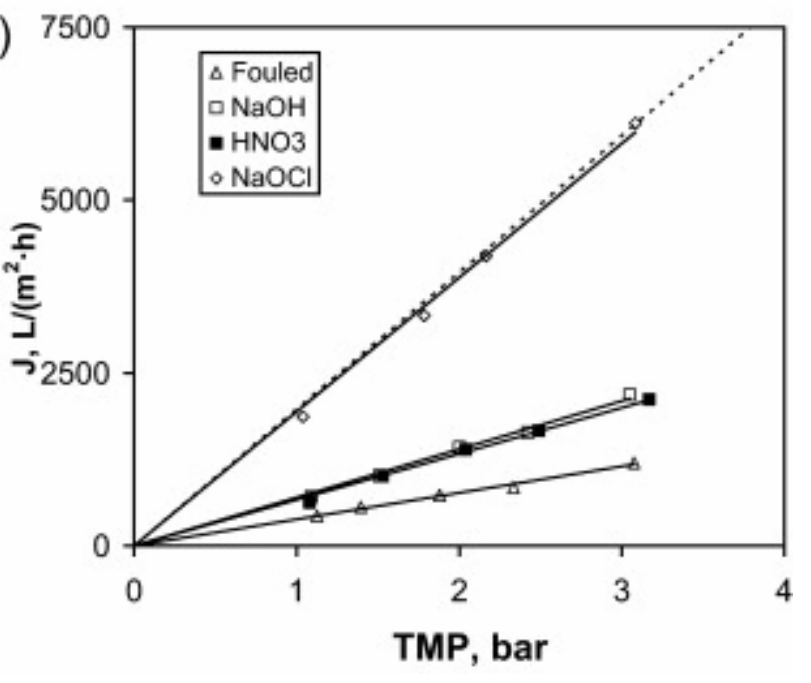

